\title{
List of black and white figures
}

1.1 Vera's four-stage cycle.

2.1 The Wood of Caledon from Ptolemy's description. 21

2.2 The oaken roof of Darnaway Castle. 38

3.1 Strathnaver according to Pont and Blaeu. 50

3.2 Ben Alder and its environs according to Gordon and Blaeu. $\quad 54$

3.3 The woods of Glencoe according to Pont. 56

3.4 Plan of the battlefield of Glenshiel. 58

4.1 A birlinn on the Macleod tomb at Rodel, Harris. 82

4.2 The pine roof of Castle Grant. 85

4.3 Plan of a cruck-framed building at Corrimony, Inverness-shire. 87

4.4 An apparent creel house in the central Highlands. 94

4.5 Interior of a byre, Isle of Jura. 96

5.1 Cadzow's medieval hunting park, Lanarkshire. 107

5.2 Summer grazing of cattle on Loch Lomondside. 116

5.3 Strathmore in Sutherland, with a creel house. 121

6.1 Inveraray Castle, Argyll. 130

6.2 Timber-fronted buildings in Hyndford's Close, Edinburgh. 132

6.3 The ceiling of Gladstone's Land, Edinburgh. 133

6.4 The Forest of Mar and Glen Quoich. 145

$\begin{array}{ll}\text { 7.1 Types of wood dyke in Sunart. } & 167\end{array}$

7.2 Ancient dyke and oak, Firbush, Lochtayside. 168

7.3 Heraldic seal of the Earls of Angus. 169

7.4 Plan for dyking an oak plantation in Argyll, 1754.169

8.1 Glen Affric in 1929.

8.2 Floating wood down Strathglass, 1795 . 210

8.3 Plaque from Glenmore presented to the Duke of Gordon, 1805. 219

9.1 Sir George Hay, first Earl of Kinnoull. 230

9.2 A view of Bonawe, Loch Etive, in 1836 . 240

9.3 The buildings of the Lorn Furnace at Bonawe. 242

10.1 Turning bobbins at Gateside Mill, Fife. 265

$\begin{array}{ll}\text { 10.2 The bucket mill at Finzean, Aberdeenshire. } & 267\end{array}$

10.3 The pyroligneous acid works at Balmaha. 268

10.4 The scaffolding of the Clyde shipyards. 273 
The Native Woodlands of Scotland, 1500-1920

11.1 John Peter Grant of Rothiemurchus.

12.1 Plan of the Cromwellian fortress at Inverness.

14.1 Plan of unenclosed woods on Sleat, Skye, 1763. 368

15.1 Niche preferences of wood ants. 